\title{
Article \\ Predicting Drug Release Rate of Implantable Matrices and Better Understanding of the Underlying Mechanisms through Experimental Design and Artificial Neural Network-Based Modelling
}

\author{
Ernő Benkő ${ }^{1}$, Ilija German Ilič ${ }^{2}{ }^{\mathbb{D}}$, Katalin Kristó ${ }^{1} \mathbb{D}$, Géza Regdon, Jr. ${ }^{1} \mathbb{1}$, Ildikó Csóka ${ }^{1} \mathbb{C}$, Klára Pintye-Hódi ${ }^{1}$, \\ Stane Srčič ${ }^{2}$ and Tamás Sovány ${ }^{1, *(\mathbb{D})}$ \\ 1 Institute of Pharmaceutical Technology and Regulatory Affairs, University of Szeged, Eötvös u. 6, \\ H-6720 Szeged, Hungary; benko.erno.mate@egis.hu (E.B.); kristo.katalin@szte.hu (K.K.); \\ geza.regdon@pharm.u-szeged.hu (G.R.J.); csoka.ildiko@szte.hu (I.C.); \\ klara.hodi@pharm.u-szeged.hu (K.P.-H.) \\ 2 Department of Pharmaceutical Technology, University of Ljubljana, Aškerčeva cesta 7, \\ SI-1000 Ljubljana, Slovenia; ilija.german.ilic@ffa.uni-lj.si (I.G.I.); stanko.srcic@ffa.uni-lj.si (S.S.) \\ * Correspondence: sovany.tamas@szte.hu; Tel.: +36-62545576
}

check for updates

Citation: Benkő, E.; Ilič, I.G.; Kristó, K.; Regdon, G., Jr.; Csóka, I.; Pintye-Hódi, K.; Srčič, S.; Sovány, T. Predicting Drug Release Rate of Implantable Matrices and Better Understanding of the Underlying Mechanisms through Experimental Design and Artificial Neural Network-Based Modelling. Pharmaceutics 2022, 14, 228. https://doi.org/10.3390/ pharmaceutics14020228

Academic Editor: Alyssa Panitch

Received: 2 December 2021

Accepted: 14 January 2022

Published: 19 January 2022

Publisher's Note: MDPI stays neutral with regard to jurisdictional claims in published maps and institutional affiliations.

Copyright: (c) 2022 by the authors. Licensee MDPI, Basel, Switzerland. This article is an open access article distributed under the terms and conditions of the Creative Commons Attribution (CC BY) license (https:// creativecommons.org/licenses/by/ $4.0 /)$.

\begin{abstract}
There is a growing interest in implantable drug delivery systems (DDS) in pharmaceutical science. The aim of the present study is to investigate whether it is possible to customize drug release from implantable DDSs through drug-carrier interactions. Therefore, a series of chemically similar active ingredients (APIs) was mixed with different matrix-forming materials and was then compressed directly. Compression and dissolution interactions were examined by FT-IR spectroscopy. Regarding the effect of the interactions on drug release kinetics, a custom-made dissolution device designed for implantable systems was used. The data obtained were used to construct models based on artificial neural networks (ANNs) to predict drug dissolution. FT-IR studies confirmed the presence of $\mathrm{H}$-bond-based solid-state interactions that intensified during dissolution. These results confirmed our hypothesis that interactions could significantly affect both the release rate and the amount of the released drug. The efficiencies of the kinetic parameter-based and point-to-point ANN models were also compared, where the results showed that the point-to-point models better handled predictive inaccuracies and provided better overall predictive efficiency.
\end{abstract}

Keywords: drug-excipient interaction; polymers; nondegradable; matrix tablet; controlled release; design of experiments; artificial neural networks

\section{Introduction}

Matrix tablets belong to the most popular systems for controlled delivery of drugs. Drug liberation from porous matrices is a complex process, influenced by numerous parameters such as solubility, matrix porosity [1], swelling [2] and gel formation [3] of polymers. The gel properties are influenced by particle size [1,4] or by the molecular weight of polymers [5] and they generally determine the drug transport within the matrix, which may be diffusion-driven [2], relaxation-driven [6], external mass-transport-driven or anomalous [7]. Especially, the anomalous transport mechanism presupposes the presence of interparticle interactions within the system [5,7]. Novel achievements require the reconsideration of traditional thinking about inert excipients, and they turn the investigation and utilization of drug-excipient interactions into a focus of the development of tailored drug delivery systems.

Most of the polymers used as pharmaceutical excipients can form supramolecular conjugates [8], and the resulting H-bond-based, ionic drug excipient [9], or excipientexcipient [10] interactions may provide an ideal way to customize drug release. The 
formation of supramolecular interactions is most likely in dissolution or melt-based production processes, but de Robertis et al. described the occurrence of similar interactions in directly compressed systems [11]. In our previous study, we examined the release of risedronate sodium from biodegradable and non-degradable implants. Although the slowest release rate has been shown in low porosity non-degradable systems, unexpectedly prolonged, sustained release was observed in the degradable systems even after complete matrix disintegration. This was due to a strong H-bond-based interaction between risedronate sodium and chitosan, suggesting that the role and presence of intermolecular interactions in the drug release rate of directly compressed matrices could be significantly underestimated [12].

Therefore, the primary goal of the present study is to confirm the hypothesis that drugexcipient interactions can be used to further prolong drug release from non-degradable matrices, while the strength of the interactions can be predicted based on the acid strength of the drugs.

To confirm the primary hypothesis, the original PVC matrix was combined with Eudragit of different grades as a model excipient, which allowed for the development of drug-binder interactions, which are mentioned as a favourable choice to produce controlledrelease DDSs. Weak base Eudragit E100 and acidic Eudragit L100-55 are commonly used for oral administration, but recent reports [13-19] have investigated their applicability in parenteral drug administration. Following intramuscular administration of Eudragit-based nanoparticles, safety tests were performed [18] to examine liver and skeletal muscle damage during the 6-week experiment. Tissue samples from the liver were similar to the control group; skeletal muscle showed inflammation in the first week, which decreased by the second week; at the end of the experiment, it became similar to the control group as well. In the case of intravenous microparticulate administration [13], only local inflammation was observed. Overall, the use of these materials as implantable excipients is considerable, especially because quaternerised Eudragit can facilitate paracellular API permeation at $\mathrm{pH}$ 7.4, which highlights the benefits of Eudragit copolymers.

A quality by design based approach was used to investigate the effect of critical material attributes on the mechanical properties of the matrices, the strength of the interaction, and the drug release rate. Design of experiments (DoE) was used to reveal basic relationships, while artificial neural networks (ANN) were used for the prediction of drug dissolution of the designed matrices. ANNs are commonly used types of machine learning/deep learning methods which mimic the signal transduction and learning mechanism of the human brain. ANNs can self-accommodate to the learning environment and are therefore widely applied for modelling of difficult nonlinear problems in a wide range of applications, including pharmaceutics. Previous studies $[20,21]$ have demonstrated that ANNs are excellent tools for modelling the mechanical properties of tablets, whereas Galata et al. had successfully used ANNs to model drug release from hydrophilic, sustainedrelease matrix systems [22] by point-to-point modelling of drug release. Nevertheless, the question of how the developed network may be used for the modelling of general problems remained open. A secondary objective of the present study was to reveal if the tested material attributes will enable a generalized prediction of drug dissolution, and furthermore, another objective was to compare the efficiency of point-to-point modelling with another method where kinetic parameters (shape parameters of the dissolution curve) served as output variables.

\section{Materials and Methods}

\subsection{Materials}

Aceclofenac (ACE) was a kind gift from ExtractumPharma Ltd. (Budapest, Hungary), while diclofenac sodium (DIS), paracetamol (PAR) and polyvinyl chloride (polymerization degree: 60-150) (PVC) were kindly gifted by Gedeon Richter Plc. (Budapest, Hungary). A powder form of Eudragit E100, Eudragit EPO (EE) and Eudragit L100-55 (EL) was supplied 
by Evonik Industries AG (Essen, Germany). The main physicochemical properties of raw materials are summarized in Table 1.

Table 1. Physicochemical properties of raw materials.

\begin{tabular}{ccccccc}
\hline & Paracetamol & Diclofenac Sodium & Aceclofenac & EUDR-E & EUDR-L & PVC \\
\hline $\begin{array}{c}\text { Solubility }(\mathrm{pH} \\
7.4)\end{array}$ & $\begin{array}{c}18-21 \\
\mathrm{mg} / \mathrm{mL}\end{array}$ & $\begin{array}{c}5.15 \\
\mathrm{mg} / \mathrm{mL}\end{array}$ & $\begin{array}{c}4.0-12.8 \\
\mathrm{mg} / \mathrm{mL}\end{array}$ & $\begin{array}{c}<10 \mu \mathrm{g} / \mathrm{mL} \\
(>\mathrm{pH} 5)\end{array}$ & $\begin{array}{c}<0.03 \mathrm{mg} / \mathrm{mL} \\
(>\mathrm{pH} 6)\end{array}$ & $-<10 \mu \mathrm{g} / \mathrm{mL}$ \\
\hline $\log \mathrm{P}$ & 0.34 & 3.10 & 4.16 & - & - & - \\
\hline $\mathrm{pKa}$ & 9.46 & 4.00 & 3.44 & 10 & $3 / \mathrm{n}^{*}$ & $3 / \mathrm{n}^{*}$ \\
\hline H+ acceptor & 2 & 2 & 4 & $0 / \mathrm{n}^{*}$ & $1 / \mathrm{n}^{*}$ & - \\
\hline H+ donor & 2 & 2 & 2 & - & - & - \\
\hline Rotable bonds & 3 & 3 & 5 & - & - \\
\hline
\end{tabular}

${ }^{*} \mathrm{x} / \mathrm{n}$ : represents the number of $\mathrm{H}+$ acceptor/donor groups per monomer.

\subsection{Methods}

\subsubsection{Tablet Preparation}

Tablets were prepared according to a mixed 2- and 3-level factorial design, where the acidic or basic nature of excipients (e.g., the use of Eudragit E or L) was studied as 2-level, while the acidic strength of API, the weight ratio of excipients and the applied compression force were studied as 3-level factors. The detailed experimental plan is shown in Table 2.

Table 2. DoE plan.

\begin{tabular}{|c|c|c|c|c|c|c|c|}
\hline \multicolumn{2}{|c|}{$\begin{array}{c}\text { Compression Pressure } \\
(\mathrm{MPa})\left(\mathrm{x}_{1}\right)\end{array}$} & \multicolumn{2}{|c|}{$\begin{array}{c}\text { Eudragit/PVC Ratio } \\
(\% / \%)\left(x_{2}\right)\end{array}$} & \multicolumn{2}{|c|}{$\operatorname{API}\left(x_{3}\right)$} & \multicolumn{2}{|c|}{ Eudragit Type $\left(x_{4}\right)$} \\
\hline Level & Value & Level & Value & Level & Value & Level & Value \\
\hline \multirow{18}{*}{-1} & \multirow{18}{*}{75} & \multirow{6}{*}{-1} & \multirow{6}{*}{$25 / 75$} & \multirow{2}{*}{-1} & \multirow{2}{*}{ Paracetamol } & -1 & Eudragit $\mathrm{E}$ \\
\hline & & & & & & +1 & Eudragit L \\
\hline & & & & \multirow{2}{*}{0} & \multirow{2}{*}{ Diclofenac Sodium } & -1 & Eudragit E \\
\hline & & & & & & +1 & Eudragit L \\
\hline & & & & \multirow{2}{*}{+1} & \multirow{2}{*}{ Aceclofenac } & -1 & Eudragit $\mathrm{E}$ \\
\hline & & & & & & +1 & Eudragit L \\
\hline & & \multirow{6}{*}{0} & \multirow{6}{*}{$50 / 50$} & \multirow{2}{*}{-1} & \multirow{2}{*}{ Paracetamol } & -1 & Eudragit $\mathrm{E}$ \\
\hline & & & & & & +1 & Eudragit L \\
\hline & & & & \multirow{2}{*}{0} & \multirow{2}{*}{ Diclofenac Sodium } & -1 & Eudragit E \\
\hline & & & & & & +1 & Eudragit L \\
\hline & & & & \multirow{2}{*}{+1} & \multirow{2}{*}{ Aceclofenac } & -1 & Eudragit $\mathrm{E}$ \\
\hline & & & & & & +1 & Eudragit L \\
\hline & & \multirow{6}{*}{+1} & \multirow{6}{*}{$75 / 25$} & \multirow{2}{*}{-1} & \multirow{2}{*}{ Paracetamol } & -1 & Eudragit $\mathrm{E}$ \\
\hline & & & & & & +1 & Eudragit L \\
\hline & & & & \multirow{2}{*}{0} & \multirow{2}{*}{ Diclofenac Sodium } & -1 & Eudragit $\mathrm{E}$ \\
\hline & & & & & & +1 & Eudragit L \\
\hline & & & & \multirow{2}{*}{+1} & \multirow{2}{*}{ Aceclofenac } & -1 & Eudragit E \\
\hline & & & & & & +1 & Eudragit L \\
\hline
\end{tabular}


Table 2. Cont.

\begin{tabular}{|c|c|c|c|c|c|c|c|}
\hline \multicolumn{2}{|c|}{$\begin{array}{c}\text { Compression Pressure } \\
(\mathrm{MPa})\left(\mathrm{x}_{1}\right)\end{array}$} & \multicolumn{2}{|c|}{$\begin{array}{c}\text { Eudragit/PVC Ratio } \\
(\% / \%)\left(x_{2}\right)\end{array}$} & \multicolumn{2}{|c|}{$\operatorname{API}\left(x_{3}\right)$} & \multicolumn{2}{|c|}{ Eudragit Type $\left(x_{4}\right)$} \\
\hline Level & Value & Level & Value & Level & Value & Level & Value \\
\hline \multirow{18}{*}{0} & \multirow{18}{*}{225} & \multirow{6}{*}{-1} & \multirow{6}{*}{$25 / 75$} & \multirow{2}{*}{-1} & \multirow{2}{*}{ Paracetamol } & -1 & Eudragit E \\
\hline & & & & & & +1 & Eudragit L \\
\hline & & & & \multirow{2}{*}{0} & \multirow{2}{*}{ Diclofenac Sodium } & -1 & Eudragit E \\
\hline & & & & & & +1 & Eudragit L \\
\hline & & & & \multirow{2}{*}{+1} & \multirow{2}{*}{ Aceclofenac } & -1 & Eudragit E \\
\hline & & & & & & +1 & Eudragit L \\
\hline & & \multirow{6}{*}{0} & \multirow{6}{*}{$50 / 50$} & \multirow{2}{*}{-1} & \multirow{2}{*}{ Paracetamol } & -1 & Eudragit E \\
\hline & & & & & & +1 & Eudragit L \\
\hline & & & & \multirow{2}{*}{0} & \multirow{2}{*}{ Diclofenac Sodium } & -1 & Eudragit E \\
\hline & & & & & & +1 & Eudragit L \\
\hline & & & & \multirow{2}{*}{+1} & \multirow{2}{*}{ Aceclofenac } & -1 & Eudragit E \\
\hline & & & & & & +1 & Eudragit L \\
\hline & & \multirow{6}{*}{+1} & \multirow{6}{*}{$75 / 25$} & \multirow{2}{*}{-1} & \multirow{2}{*}{ Paracetamol } & -1 & Eudragit E \\
\hline & & & & & & +1 & Eudragit L \\
\hline & & & & 0 & Diclofenac Sodium & -1 & Eudragit E \\
\hline & & & & & & +1 & Eudragit L \\
\hline & & & & 1 & A coclofonas & -1 & Eudragit E \\
\hline & & & & +1 & Aceciolentac & +1 & Eudragit L \\
\hline & & & & 1 & Parncotamol & -1 & Eudragit E \\
\hline & & & & -1 & I aracetamor & +1 & Eudragit L \\
\hline & & -1 & $25 / 75$ & 0 & Diclofenas Sodium & -1 & Eudragit E \\
\hline & & & & 0 & Dicioienac soumumt & +1 & Eudragit L \\
\hline & & & & 1 & 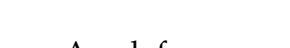 & -1 & Eudragit E \\
\hline & & & & +1 & Aceclofenac & +1 & Eudragit L \\
\hline & & & & -1 & Parncotamol & -1 & Eudragit E \\
\hline & & & & -1 & I aracetamor & +1 & Eudragit L \\
\hline+1 & 375 & 0 & $50 / 50$ & 0 & Dislofonos Codium & -1 & Eudragit $\mathrm{E}$ \\
\hline & & & & & Dicioietrac soumumt & +1 & Eudragit L \\
\hline & & & & 1 & A coslofonas & -1 & Eudragit E \\
\hline & & & & +1 & Aceciolenac & +1 & Eudragit L \\
\hline & & & & -1 & Paracetamol & -1 & Eudragit E \\
\hline & & & & & Paracetamor & +1 & Eudragit L \\
\hline & & +1 & $75 / 25$ & 0 & Diclofanas Sodium & -1 & Eudragit E \\
\hline & & & & & & +1 & Eudragit L \\
\hline & & & & 1 & A collofonos & -1 & Eudragit E \\
\hline & & & & +1 & Aceciorenac & +1 & Eudragit L \\
\hline
\end{tabular}

Powder mixing was made with a Paul Schatz principle based 1.5 L mixer (Inversina, BioEngineering, Wald, Switzerland) at $45 \mathrm{rpm}$ for $8 \mathrm{~min}$ and then for another $2 \mathrm{~min}$ with the addition of $1 \%$ magnesium stearate as lubricant. The mixtures were compressed with 
an instrumented Kilian SP 300 hydraulic press (IMA Kilian GmbH \& Co., KG, Cologne, Germany) using $7 \mathrm{~mm}$-diameter punches with a bevelled edge. The mixtures were loaded into the die manually then compressed in a semi-automatic 'jogging' mode with the application of 2.9, 8.7, or $14.4 \mathrm{kN}$ compression force $(75,225$ and $375 \mathrm{MPa}$ compression pressure, respectively).

\subsubsection{Physical Properties}

The physical characterization of tablets was made with a Kraemer UTS tablet tester (Kraemer Elektronik GmbH, Germany). Mass, hardness, thickness and diameter were measured. The true density of matrices $\left(\rho_{\text {true }}\right)$ was determined with a helium gas pycnometer (AccuPyc 1330, Micromeritics, Norcross, GA, USA), while apparent density $\left(\rho_{\text {app }}\right)$ was calculated from their mass and physical dimensions. Then, porosity $(\varepsilon)$ was obtained according to the following equation (Equation (1)):

$$
\varepsilon=1-\left(\rho_{\text {app }} / \rho_{\text {true }}\right)
$$

\subsubsection{Physicochemical Characterization}

For the specific identification and characterization of interactions, FT-IR spectra were acquired. ZeSe HATR accessory was used, and measurements were taken with a resolution of $4 \mathrm{~cm}^{-1}$, a scan number of 128 , with $\mathrm{CO}_{2}$ and $\mathrm{H}_{2} \mathrm{O}$ correction. Spectral data were evaluated with SpectraGryph software v1.2.10 (Dr. F. Menges, Berchtesgaden, Germany).

\subsubsection{Dissolution Tests}

According to the requirements of implantable matrix systems, a custom-made dissolution tester was applied, imitating the dissolution environment of the tissue matrix and the shearing properties of other flow-through equipment [13]. Tablets were placed into Erlenmeyer flasks containing $50 \mathrm{~mL}$ of $\mathrm{pH} 7.4$ phosphate buffered saline solution. The dissolution medium was circulated with an Alitea-XV (Alitea, Sweden) peristaltic pump using a flow rate of $2 \mathrm{~mL} / \mathrm{min}$. Due to the vast number of samples to be studied, $24 \mathrm{~h}$ dissolution tests were conducted for all compositions to obtain the most important kinetic parameters, and only those samples were selected afterwards for a one-week study in which the lowest release rates were observed. The concentration gradient was continuously maintained by mimicking the time related systemic renewing of the body fluids. Therefore, in the $24 \mathrm{~h}$ long experiments $2.5,5,5,5,10$, and $20 \mathrm{~mL}$ samples were taken and replaced with fresh medium after 15 and $30 \mathrm{~min}$ and 1, 2, 4, and $8 \mathrm{~h}$, respectively, while the last samples were taken after $24 \mathrm{~h}$. In the case of the one-week study, 5, 5, 10, 20, 35, 35, and $35 \mathrm{~mL}$ volumes were sampled and refreshed as above after $1,2,4,8,24,48$, and $72 \mathrm{~h}$, respectively, while the last samples were taken after $168 \mathrm{~h}$. From each composition, three parallel measurements were taken. Quantitative analysis was made with a ThermoGenesys UV-spectrometer at a wavelength of $274 \mathrm{~nm}$ for aceclofenac, $276 \mathrm{~nm}$ for diclofenac sodium and $244 \mathrm{~nm}$ in the case of paracetamol. The dissolution kinetics was characterized according to the Korsmeyer-Peppas equation (Equation (2)).

$$
M_{t} / M_{0}=k t^{n}
$$

where $M_{0}$ is the initial drug amount in the matrix, $M_{t}$ is the drug amount at the given time $(t), k$ is the dissolution rate constant and $n$ is the release exponent regarding the diffusion mechanism.

\subsubsection{Design of Experiments and Artificial Neural Networks}

DoE analysis and ANN modelling were performed with Statistica v.13.5.0.17 (Tibco Software Inc., Palo Alto, CA, USA). Compression pressure $\left(\mathrm{x}_{1}\right)$, amount of excipient $\left(\mathrm{x}_{2}\right)$, $\operatorname{API}\left(\mathrm{x}_{3}\right)$ and excipient used $\left(\mathrm{x}_{4}\right)$ were examined as independent factors, while hardness $\left(\mathrm{y}_{1}\right)$, porosity $\left(\mathrm{y}_{2}\right)$ and release rate $\left(\mathrm{y}_{3}\right)$ were used as optimization parameters in the DoE analysis. 
The secondary objective of the present study was to compare the effectiveness of various modelling approaches to enable generalized prediction of drug dissolution rates from different matrices. In kinetic-based modelling, the release rate and release exponent were used as the output of the ANN model, while in point-to-point modelling, the dissolved amount of drug at the various sampling times was applied according to Galata et al. [22], which included 7 data points. Our hypothesis is that kinetic-based modelling allows for a simplified network structure and faster generalization. To clarify the importance of different input parameters for predictive accuracy, 3 different parameter combinations were used to train the ANNs for both kinetic based and point-to-point modelling. A list of inputs used in the different training approaches is provided in Table 3, while a detailed data set for training, testing, and validating ANNs is provided in Table S1.

Table 3. Input variables of the various ANN training approaches.

\begin{tabular}{|c|c|c|c|c|c|c|}
\hline \multirow{2}{*}{$\begin{array}{c}\text { Modelling } \\
\text { Type }\end{array}$} & Approach 1 & Approach 2 & Approach 3 & Approach 4 & Approach 5 & Approach 6 \\
\hline & Kinetic Based & Kinetic Based & Kinetic Based & Point-to-Point & Point-to-Point & Point-to-Point \\
\hline \multicolumn{7}{|l|}{$\begin{array}{c}\text { Input } \\
\text { variable }\end{array}$} \\
\hline Drug & $x$ & & & $x$ & & \\
\hline $\begin{array}{c}\text { Drug } \\
\text { solubility }(\mathrm{mg} / \mathrm{mL})\end{array}$ & & $x$ & $x$ & & $x$ & $x$ \\
\hline Drug pKa & & $x$ & $x$ & & $x$ & $x$ \\
\hline Excipient & $x$ & & & $x$ & & \\
\hline $\begin{array}{c}\text { Excipient } \\
\text { solubility }(\mathrm{mg} / \mathrm{mL})\end{array}$ & & $x$ & $x$ & & $x$ & $x$ \\
\hline Excipient $\mathrm{pKa}$ & & $x$ & $x$ & & $x$ & $x$ \\
\hline $\begin{array}{c}\text { Excipient } \\
\text { amount (\%) }\end{array}$ & $x$ & $x$ & $x$ & $x$ & $x$ & $x$ \\
\hline $\begin{array}{l}\text { Compression } \\
\text { pressure }(\mathrm{MPa})\end{array}$ & $x$ & $x$ & $x$ & $x$ & $x$ & $x$ \\
\hline Hardness & & & $x$ & & & $x$ \\
\hline Porosity & & & $x$ & & & $x$ \\
\hline Peak Shift & $x$ & $x$ & $x$ & $x$ & $x$ & $x$ \\
\hline
\end{tabular}

Feed-forward, back-propagation multilayer perceptron networks were developed in all cases. The networks were trained with BFGS algorithm. The number of hidden neurons was gradually increased in a dynamic system depending on the number of input and output neurons: $I+O-3 \leq n \leq I+O+1$, where $I$ is the number of inputs $O$ is the number outputs and $n$ is number of hidden neurons; thus, the hidden neuron number varied from 4-8, 6-10, 8-12, 9-13, 11-15, 13-17 in cases of approach 1-6, respectively.

A multistart method including 10,000 networks was applied using the automated neural networks module of Statistica with each hidden neuron number, including a training approach to screen the best performing network with different initialization patterns and activation functions for hidden and output neurons. The training was stopped when the root mean square error (RMSE) of test the dataset reached its minimum. The 5 best performing networks from each multistart run were retained for further analysis.

The prediction performance of the networks was evaluated based on network perfection, which is the mean $\mathrm{R}^{2}$ of the observed vs. predicted data of each output neuron, and on the RMSE of predictions on the validation subset. 


\section{Results and Discussion}

\subsection{Physical Parameters}

The physical parameters of the tablets are shown in Table 4, while the statistical evaluation of the effect of compression pressure $\left(\mathrm{x}_{1}\right)$, amount of excipient $\left(\mathrm{x}_{2}\right)$, API $\left(\mathrm{x}_{3}\right)$ and excipient used $\left(\mathrm{x}_{4}\right)$ on hardness $\left(\mathrm{y}_{1}\right)$ and porosity $\left(\mathrm{y}_{2}\right)$ of the various compositions are displayed in Equations (3) and (4), respectively. The presented equations provided the best fit; for the equations containing the full set of the acquired factor effects and their interactions, please see the Supplementary Materials. The significant factors and factor interactions are highlighted in boldface in all cases.

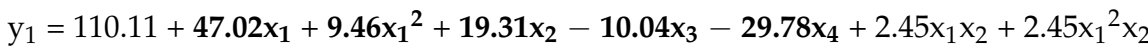

$$
\begin{aligned}
& +2.29 \mathrm{x}_{1}{ }^{2} \mathrm{x}_{2}{ }^{2}-6.31 \mathrm{x}_{1} \mathrm{x}_{3}-4.29 \mathrm{x}_{1}{ }^{2} \mathrm{x}_{3}+4.96 \mathrm{x}_{1} \mathrm{x}_{3}{ }^{2}-3.62 \mathrm{x}_{1}{ }^{2} \mathrm{x}_{3}{ }^{2}-3.32 \mathrm{x}_{2} \mathrm{x}_{3}{ }^{2}-11.48 \mathrm{x}_{2} \mathrm{x}_{4}- \\
& 2.24 \mathrm{x}_{2}{ }^{2} \mathrm{x}_{4}-2.33 \mathrm{x}_{3} \mathrm{x}_{4}+6.83 \mathrm{x}_{3}{ }^{2} \mathrm{x}_{4} \\
& R^{2}=0.9743 \text { adj. } R^{2}=0.9599 \text { MS Res }=123.02
\end{aligned}
$$

$$
\begin{aligned}
& \mathrm{y}_{2}=0.133-0.053 \mathrm{x}_{1}-0.023 \mathrm{x}_{1}{ }^{2}-0.046 \mathrm{x}_{3}+0.018 \mathrm{x}_{4}+0.024 \mathrm{x}_{1} \mathrm{x}_{2}-0.019 \mathrm{x}_{1} \mathrm{x}_{2}{ }^{2}+
\end{aligned}
$$

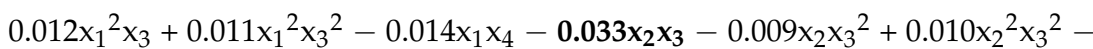

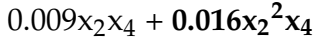

\begin{tabular}{|c|c|c|c|c|c|c|c|c|c|c|c|c|c|}
\hline $\begin{array}{l}\text { Eudragit/PVC } \\
\text { Ratio }(\% / \%)\end{array}$ & $\begin{array}{l}\text { Compression } \\
\text { Pressure } \\
\text { (MPa) }\end{array}$ & Composition & $\begin{array}{l}\text { Mass } \\
(\mathrm{mg})\end{array}$ & $\begin{array}{l}\text { Hardness } \\
\text { (N) }\end{array}$ & Porosity & Composition & $\begin{array}{l}\text { Mass } \\
(\mathrm{mg})\end{array}$ & $\begin{array}{l}\text { Hardness } \\
\text { (N) }\end{array}$ & Porosity & Composition & $\begin{array}{l}\text { Mass } \\
(\mathrm{mg})\end{array}$ & $\begin{array}{l}\text { Hardness } \\
\text { (N) }\end{array}$ & Porosity \\
\hline \multirow{3}{*}{$25 / 75$} & 75 & & 147.0 & 15.0 & 0.307 & \multirow{9}{*}{$\begin{array}{c}\text { DIS- } \\
\text { PVC-EL }\end{array}$} & 152.1 & 8.0 & 0.423 & \multirow{9}{*}{$\begin{array}{c}\text { ACE- } \\
\text { PVC-EL }\end{array}$} & 144.5 & 13.5 & 0.279 \\
\hline & 225 & & 147.9 & 114.3 & 0.136 & & 135.2 & 118.5 & 0.125 & & 131.4 & 68.2 & 0.077 \\
\hline & 375 & PAR- & 141.6 & 109.1 & 0.118 & & 202.6 & 140.7 & 0.082 & & 131.2 & 103.6 & 0.067 \\
\hline \multirow{3}{*}{$50 / 50$} & 75 & & 149.0 & 18.7 & 0.290 & & 154.2 & 34.0 & 0.236 & & 152.7 & 22.9 & 0.232 \\
\hline & 225 & & 135.9 & 95.8 & 0.122 & & 138.7 & 92.0 & 0.128 & & 137.8 & 65.8 & 0.104 \\
\hline & 375 & & 142.2 & 133.6 & 0.111 & & 146.9 & 134.4 & 0.058 & & 142.4 & 71.3 & 0.097 \\
\hline \multirow{3}{*}{$75 / 25$} & 75 & & 147.0 & 28.2 & 0.306 & & 153.8 & 27.3 & 0.026 & & 147.7 & 15.2 & 0.027 \\
\hline & 225 & & 151.7 & 132.6 & 0.118 & & 136.9 & 97.0 & 0.137 & & 134.9 & 90.7 & 0.086 \\
\hline & 375 & & 149.7 & 153.8 & 0.091 & & 121.5 & 153.8 & 0.100 & & 137.1 & 116.7 & 0.060 \\
\hline \multirow{3}{*}{$25 / 75$} & 75 & \multirow{9}{*}{$\begin{array}{l}\text { PAR- } \\
\text { PVC-EE }\end{array}$} & 154.8 & 113.6 & 0.223 & \multirow{9}{*}{$\begin{array}{c}\text { DIS- } \\
\text { PVC-EE }\end{array}$} & 150.4 & 94.4 & 0.092 & \multirow{9}{*}{$\begin{array}{c}\text { ACE- } \\
\text { PVC-EE }\end{array}$} & 147.3 & 93.4 & 0.106 \\
\hline & 225 & & 142.5 & 166.6 & 0.126 & & 129.0 & 130.7 & 0.098 & & 151.2 & 159.1 & 0.038 \\
\hline & 375 & & 136.1 & 184.5 & 0.098 & & 130.7 & 173.7 & 0.113 & & 152.7 & 164.7 & 0.014 \\
\hline \multirow{3}{*}{$50 / 50$} & 75 & & 149.0 & 50.1 & 0.191 & & 151.7 & 57.4 & 0.210 & & 151.1 & 67.6 & 0.141 \\
\hline & 225 & & 152.2 & 146.7 & 0.109 & & 138.8 & 102.6 & 0.101 & & 137.6 & 87.5 & 0.068 \\
\hline & 375 & & 145.2 & 161.8 & 0.105 & & 138.7 & 153.8 & 0.080 & & 139.0 & 143.6 & 0.071 \\
\hline \multirow{3}{*}{$75 / 25$} & 75 & & 149.5 & 128.6 & 0.282 & & 137.4 & 102.9 & 0.147 & & 146.3 & 131.2 & 0.102 \\
\hline & 225 & & 137.0 & 192.4 & 0.131 & & 135.8 & 160.6 & 0.121 & & 145.9 & 187.9 & 0.011 \\
\hline & 375 & & 148.6 & 211.2 & 0.115 & & 151.7 & 201.0 & 0.046 & & 141.7 & 192.8 & 0.011 \\
\hline
\end{tabular}

$$
\begin{aligned}
& \mathrm{R}^{2}=0.7627 \text { adj } \mathrm{R}^{2}=0.6775 \mathrm{MS} \text { Res }=0.0023
\end{aligned}
$$

Table 4. Physical parameters of matrices.

The porosity of the system exhibited a well-established logarithmic correlation with tablet hardness (Figure 1), and the increase in pressure resulted in stronger matrices and decrement in porosity. Nevertheless, there were some outliers, where tablets with low breaking hardness showed extremely low porosity. In such cases, radically increased dwell time was required to avoid critical tableting problems, e.g., capping, lamination, cracking, or picking. This phenomenon caused poorer fitting accuracy in case of porosity $\left(\mathrm{y}_{2}\right)$ values; thus, the results of the statistical analysis and the related conclusions should be treated with caution.

The results revealed that matrices made of EE could reach higher breaking hardness and lower porosity than the tablets made of EL. From the aspect of different weight ratios, the general conclusion is that the composites containing more methacrylate copolymer and less PVC appeared to be the strongest systems with the least porosity, while the 25:75 Eudragit-PVC ratio showed the lowest values and the highest porosity. The mean values showed that paracetamol formed the hardest, and aceclofenac formed the weakest, matrices, but in contrast with the general expectations, this was not directly proportional to the drug release rate, which supports our primary hypothesis that besides the 
matrix porosity the physicochemical properties of the applied materials, the presence of drug-carrier interactions may considerably influence drug release.

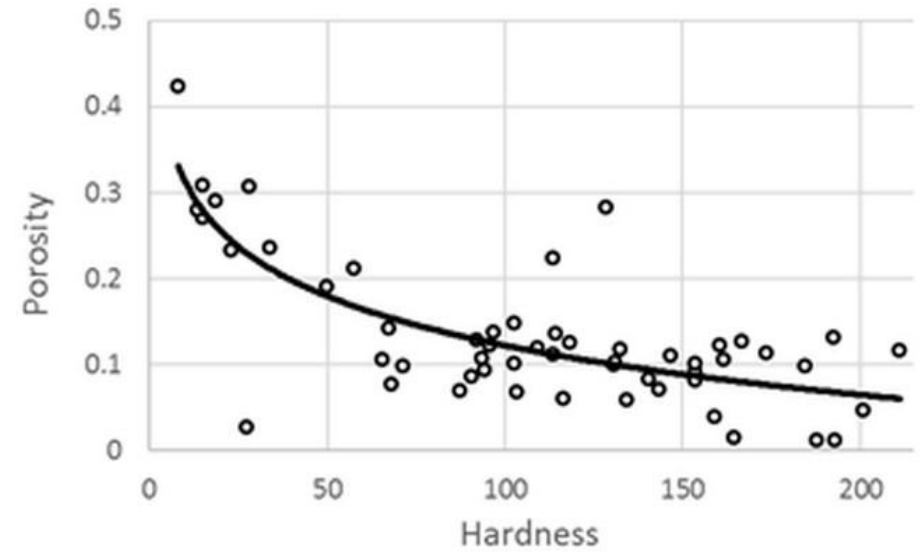

Figure 1. Hardness-porosity plot.

\subsection{Investigation of Drug-Carrier Interactions}

The FT-IR spectra of the compressed samples were used to reveal the presence of the drugexcipient interactions. The method is well applicable in various fields where chemical interactions are the area of interest $[23,24]$; the present analysis focuses on selected wavenumber ranges reasonably, where signals of $\mathrm{H}$-bond forming groups can be found.

Weak signal intensities were observed in the $-\mathrm{OH}$ stretching region $\left(3000-3600 \mathrm{~cm}^{-1}\right.$, data not displayed) for all samples, which made the drawing of proper consequences about the interaction status impossible. The further analysis therefore focuses on the $\mathrm{C}=\mathrm{O}$ stretching $\left(1600-1800 \mathrm{~cm}^{-1}\right)$ and the $\beta-\mathrm{OH}(\beta-\mathrm{NH})$ deformation vibration $\left(1200-1600 \mathrm{~cm}^{-1}\right)$ regions.

According to our primary hypothesis, the interaction potential of the studied APIs decreases in the order of ACE $>$ DIS $>>$ PAR, and stronger interactions are expected with EE than with EL in all cases. The results generally confirmed this hypothesis.

Figure 2 displays the IR spectra of ACE-PVC-EE composition, which exhibits intensive signs of drug-polymer interactions. In the carbonyl signal ( $\mathrm{C}=\mathrm{O}$ stretching) region, $\mathrm{EE}$ has a characteristic peak at $1722 \mathrm{~cm}^{-1}$, while the ACE at 1712 and at $1769 \mathrm{~cm}^{-1}$ belong to the dimerized and monomer forms, respectively. The monomeric peak of ACE $\left(1769 \mathrm{~cm}^{-1}\right)$ exhibits decreasing intensity with the increasing amount of EE (Figure 2), indicating strong conjugation between the drug and excipient. Some further changes, such as the shifting of the deformation vibration of the HNC bonds at $1415 \mathrm{~cm}^{-1}$ appears to shift to $1420 \mathrm{~cm}^{-1}$, which indicates that the corresponding molecular parts may take part in the interaction.

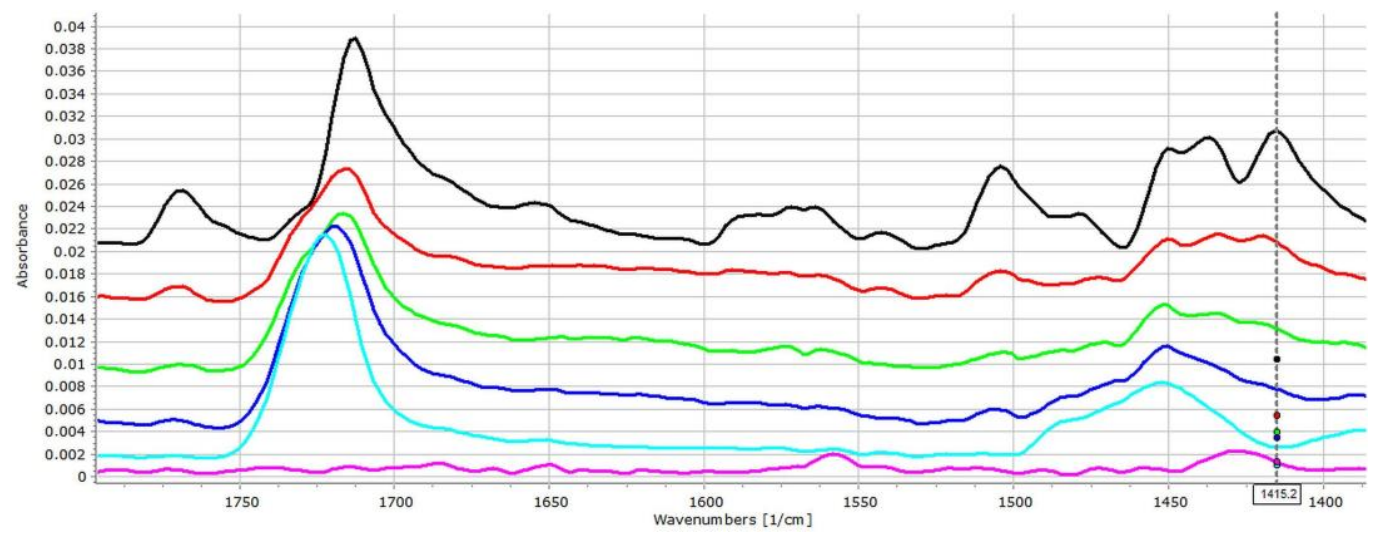

Figure 2. FT-IR spectra (1400-1800 $\mathrm{cm}^{-1}$ range) of the ACE (black), ACE-PVC:EE 75:25 (red), ACEPVC:EE 50:50 (green), ACE-PVC:EE 25:75 (deep blue), EE (light blue) and PVC (purple) samples; multicursor indicates the place of peak shift in the spectrum. 
As was expected, ACE exhibited fewer signs of interactions in relation to the acidic EL polymer (Figure 3). The presence of mild interactions by increasing the amount of the EL is supported by the slight shift of the carbonyl signal to 1715,1717 and $1719 \mathrm{~cm}^{-1}$ in the cases of 75:25, 50:50 and 25:75 PVC:EL ratios, respectively, and indicated increasing strength of interactions, which is also supported by the decreasing intensity of the unassociated acidic carbonyl absorption peak which appears at $1769 \mathrm{~cm}^{-1}$.

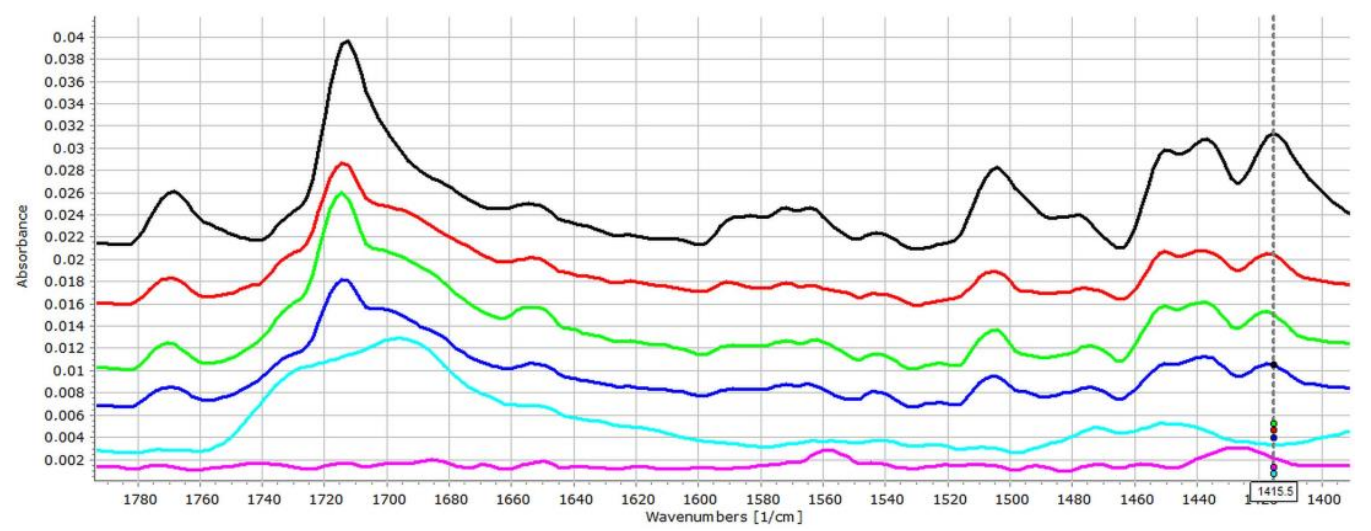

Figure 3. FT-IR spectra (1400-1800 $\mathrm{cm}^{-1}$ range) of the ACE (black), ACE-PVC:EL 75:25 (red), ACEPVC:EL 50:50 (green), ACE-PVC:EL 25:75 (deep blue), EL (light blue) and PVC (purple) samples; multicursor indicates the place of peak shift in the spectrum.

The $\beta-\mathrm{OH}$ vibration of EL appears at $1472.2 \mathrm{~cm}^{-1}$, which cannot be seen clearly in the spectra of matrices. A slight shift of the peak at 1415.3 towards $1417.8 \mathrm{~cm}^{-1}$ can be recognised, which may reflect some further changes in the environment of the diphenylamine group of the drug. This finding is in accordance with the observation of Liu et al., who confirmed that EL may form H-bond based interactions under proper circumstances [25].

To clarify the importance of the solid-state interactions, and to analyse the effect of the dissolution medium on the strength of interactions, the following experiment was performed. Tablets were dipped into $\mathrm{pH} 7.4$ buffer for $30 \mathrm{~min}$ to achieve a complete moisturization of the sample, then the excess of the water was removed, and the samples were measured with FT-IR. Nevertheless, since the presence of water in the pores completely masked the signals in the $3000-3600$ and $1550-1700 \mathrm{~cm}^{-1}$ regions, the samples were dried in desiccator for $24 \mathrm{~h}$ and measured again.

Figure 4 displays that the strength of intermolecular interactions has increased as an effect of water absorption. The characteristic peaks of $\mathrm{HCN}$ bonds from $1434 \mathrm{~cm}^{-1}$ was shifted to $1451 \mathrm{~cm}^{-1}$, while the peak at $1420 \mathrm{~cm}^{-1}$ shifted to $1405 \mathrm{~cm}^{-1}$. The characteristic peak of C-N stretching at $1252 \mathrm{~cm}^{-1}$ shifted to $1272 \mathrm{~cm}^{-1}$. These changes may also be observed in case of the dried samples, despite some re-organization due to water loss.

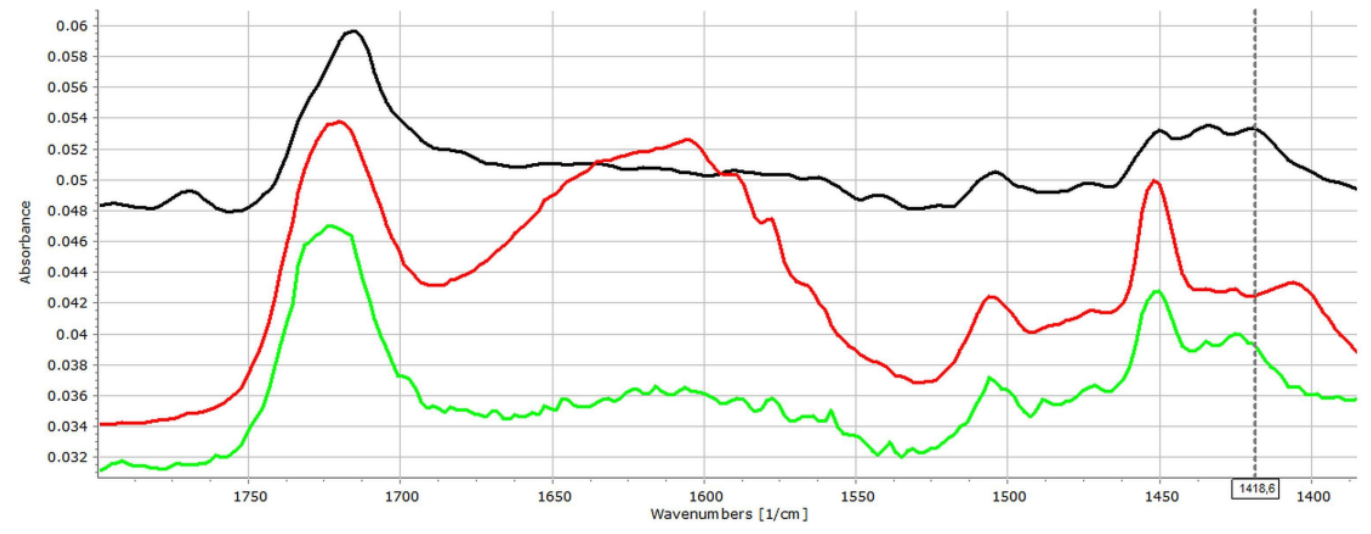

Figure 4. FT-IR spectra of ACE-PVC:EE 75:25 samples: original (black), dipped (red), and dried (green).

In the case of EL containing samples (Figure 5), similar changes may be observed in the characteristic peaks of $\mathrm{HCN}$ vibrations: the peak at $1438 \mathrm{~cm}^{-1}$ shifts to $1425 \mathrm{~cm}^{-1}$ and its intensity 
increases considerably, while and C-N stretching signal, which may be found at $1279 \mathrm{~cm}^{-1}$, shifts to $1291 \mathrm{~cm}^{-1}$.

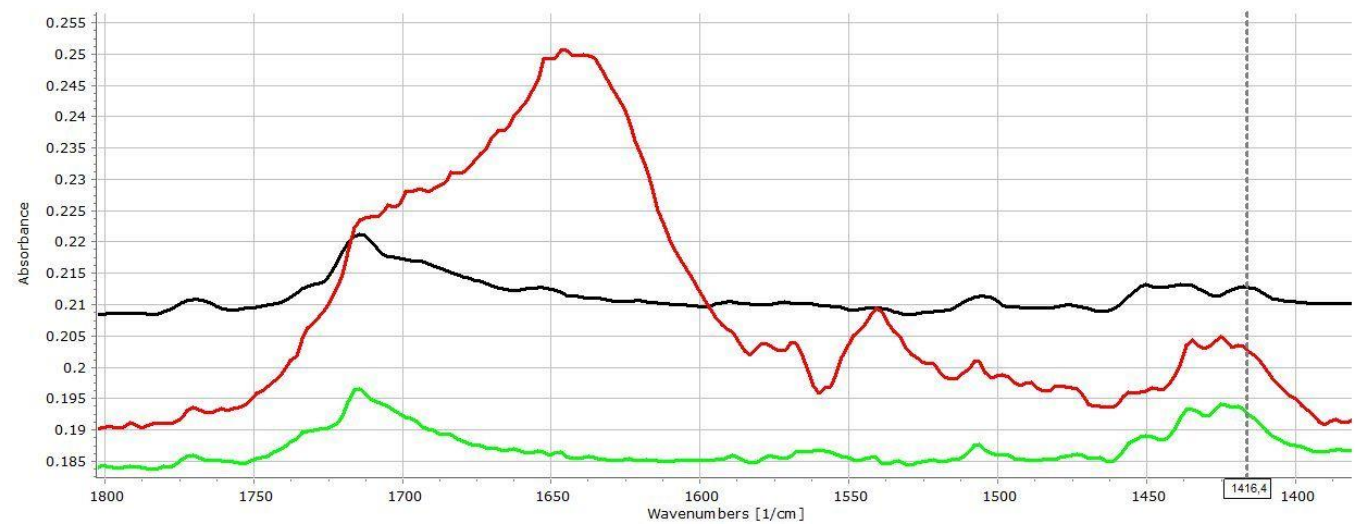

Figure 5. FT-IR spectra of ACE-PVC:EL 75:25 samples: original (black), dipped (red), and dried (green).

As expected, the matrices prepared with DIS exhibited fewer spectral changes after compression, primarily due the weaker acidity of the drug, but the higher porosity may also play a possible role in this phenomenon. Similarly, as in the ACE-containing compositions, the most obvious changes may be found in the $\mathrm{C}=\mathrm{O}$ stretching region. The characteristic peak doublet may be found at 1555 and $1571 \mathrm{~cm}^{-1}$, where the shift of the peak intensities in the direction of $1571 \mathrm{~cm}^{-1}$ may be observed with increasing Eudragit content. As expected, the shift is less intensive in the case of EL-containing compositions (Figure S1) than in EE-containing ones (Figure S2). Some further signs of mild interactions and increased intramolecular association of the $\mathrm{C}-\mathrm{O}$ bond region of EE-containing matrices may also be observed (Figure S2). The characteristic peak of DIS at $1279 \mathrm{~cm}^{-1}$ and of EE at $1269.5 \mathrm{~cm}^{-1}$ overlap around $1274 \mathrm{~cm}^{-1}$ in accordance with the increasing amount of EE.

The observed interactions were strongly intensified by the dipping. The ratio of the associated $\mathrm{C}=\mathrm{O}$ groups increased for both EE- and EL-containing matrices (Figure S3 and Figure S4, respectively), which is well visible from the increasing intensity of the associated $\mathrm{C}=\mathrm{O}$ peak at $1555 \mathrm{~cm}^{-1}$ and $1549 \mathrm{~cm}^{-1}$ for EE and EL, respectively. Further changes such as the increasing intensity of the peak at $1410 \mathrm{~cm}^{-1}$ and a peak shift from 1234 to $1248 \mathrm{~cm}^{-1}$, associated with the $\beta \mathrm{NH}$ and C-N stretching vibration, respectively, indicates that under these circumstances, the secondary amino group of DIS was also involved in the association with EE. In the case of EL, the corresponding changes may be found at 1409,1232 , and at $1250 \mathrm{~cm}^{-1}$. Other peak shifts from 1168 to $1197 \mathrm{~cm}^{-1}$ and from 1190 to $1198 \mathrm{~cm}^{-1}$ for EE and EL, respectively, confirm the presence of intermolecular associations from the side of the polymers.

In the case of PAR-containing compositions, they exhibit no obvious signs of interactions in case of EL- (Figure S5) or EE- (Figure S6) containing compositions. The only mentionable change is the slight shift of a C-N stretching peak (PAR) from 1221 to 1224 or $1226 \mathrm{~cm}^{-1}$, in the case of ELand EE-containing compositions, respectively. This finding was in accordance with our primary hypothesis and with the finding of Obediat et al., who also observed no interactions between EE and PAR in compressed matrix systems [26].

Nevertheless, after dipping the tablets into the dissolution medium, considerable changes were observed in the FT-IR spectra for both the EE- and EL-containing samples. The shift of the peaks from 1504 to $1512 \mathrm{~cm}^{-1}$ and from 1432 to $1454 \mathrm{~cm}^{-1}$ indicates the participation of the secondary amide group, while the shift of the peak from 1224 to $1239 \mathrm{~cm}^{-1}$ refers on the involvement of the phenolic -OH group into intermolecular associations (Figure S7). The shift of the characteristic peak of EE from 1170 to $1147 \mathrm{~cm}^{-1}$ suggests that the drug is connected to tertiary amino groups of the polymer.

The above-mentioned changes may be observed in case of EL-containing samples (peak shifts from 1504 to $1514 \mathrm{~cm}^{-1}$, from 1434 to $1424 \mathrm{~cm}^{-1}$ and from 1224 to $1240 \mathrm{~cm}^{-1}$ ), while the shift of the characteristic peak of EL from 1169 to $1186 \mathrm{~cm}^{-1}$ indicates that the carbonyl side groups of the polymer are involved into the association (Figure S8).

Overall, the results confirmed that solid-state drug-polymer interactions may be presented after direct compression of the materials, which were in accordance with the findings with de Robertis et al. [11]. The weak solid-state H-bonds may further strengthen during the dissolution process and may influence the drug release rate [12], or in some cases, it may even turn into the formation of polyelectrolyte complexes, as was observed by Pavli et al. [27]. 


\subsection{Dissolution Tests and Kinetic Study}

The drug release kinetics were evaluated with the use of the Korsmeyer-Peppas model (Table 5), which is the most regular type of dissolution in the case of hydrophilic matrix systems. It can be noticed from the results that the dissolution followed non-Fickian diffusion. Most $\mathrm{n}$ values represent non-Fickian kinetics, except for those below 0.45 . In the case of cylindrical shapes, Fickian diffusion has a value of 0.45 , and for spherical shapes, this value is 0.43 . The reason for having smaller values than the limitations of the model is due to the polydisperse nature of the system [28]. Particle size has a major influence on the release exponent. In addition, the geometry of tablets slightly varies from an ideal cylindrical shape.

Table 5. Release rates and release exponents derived from the Korsmeyer-Peppas model ( $24 \mathrm{~h}$ long test).

\begin{tabular}{|c|c|c|c|c|c|c|c|c|c|c|c|c|c|}
\hline $\begin{array}{c}\text { Eudragit/PVC } \\
\text { Ratio } \\
(\% / \%)\end{array}$ & $\begin{array}{l}\text { Compression } \\
\text { Pressure } \\
\text { (MPa) }\end{array}$ & Composition & $\mathbf{R}^{2}$ & k & $\mathbf{n}$ & Composition & $\mathbf{R}^{2}$ & $\mathbf{k}$ & $\mathbf{n}$ & Composition & $\mathbf{R}^{2}$ & k & $\mathbf{n}$ \\
\hline \multirow{3}{*}{$25 / 75$} & 75 & \multirow{9}{*}{ PAR-PVC-EL } & 0.9230 & 5.7937 & 0.3858 & \multirow{9}{*}{ DIS-PVC-EL } & 0.9966 & 0.0419 & 0.9833 & \multirow{9}{*}{ ACE-PVC-EL } & 0.9945 & 0.4184 & 0.7325 \\
\hline & 225 & & 0.9840 & 1.4970 & 0.5635 & & 0.9997 & 0.0092 & 1.1609 & & 0.9979 & 0.0540 & 0.9340 \\
\hline & 375 & & 0.9870 & 1.7224 & 0.5345 & & 0.9999 & 0.0054 & 1.2765 & & 0.9976 & 0.0850 & 0.8940 \\
\hline \multirow{3}{*}{$50 / 50$} & 75 & & 0.9410 & 6.8732 & 0.3534 & & 0.9867 & 1.4394 & 0.4317 & & 0.9994 & 0.1289 & 0.8756 \\
\hline & 225 & & 0.9845 & 1.6004 & 0.5377 & & 0.9979 & 0.0265 & 0.9560 & & 0.9691 & 0.1877 & 0.8271 \\
\hline & 375 & & 0.9712 & 1.5522 & 0.5594 & & 0.9942 & 0.0435 & 0.9105 & & 0.9899 & 0.0829 & 0.8931 \\
\hline \multirow{3}{*}{$75 / 25$} & 75 & & 0.9920 & 1.7155 & 0.5058 & & 0.9789 & 1.5287 & 0.5567 & & 0.9906 & 0.2466 & 0.7311 \\
\hline & 225 & & 0.9974 & 0.7570 & 0.6298 & & 0.9902 & 0.1828 & 0.7850 & & 0.9990 & 0.2002 & 0.7389 \\
\hline & 375 & & 0.9928 & 1.5108 & 0.5239 & & 0.9976 & 0.2207 & 0.6573 & & 0.9991 & 0.2055 & 0.7260 \\
\hline \multirow{3}{*}{$25 / 75$} & 75 & \multirow{9}{*}{ PAR-PVC-EE } & 0.9936 & 0.9010 & 0.5693 & \multirow{9}{*}{ DIS-PVC-EE } & 0.9660 & 1.3715 & 0.2623 & \multirow{9}{*}{ ACE-PVC-EE } & 0.9998 & 0.0376 & 0.5936 \\
\hline & 225 & & 0.9977 & 0.6775 & 0.5774 & & 0.9609 & 1.4599 & 0.2306 & & 0.9933 & 0.0097 & 0.7596 \\
\hline & 375 & & 0.9755 & 0.8078 & 0.5483 & & 0.9286 & 1.4502 & 0.2176 & & 0.9820 & 0.0106 & 0.7241 \\
\hline \multirow{3}{*}{$50 / 50$} & 75 & & 0.9915 & 1.1441 & 0.5441 & & 0.9974 & 1.7063 & 0.2739 & & 0.9877 & 0.2063 & 0.4619 \\
\hline & 225 & & 0.9973 & 0.4156 & 0.6751 & & 0.9846 & 0.9046 & 0.3542 & & 0.9972 & 0.0704 & 0.5474 \\
\hline & 375 & & 0.9978 & 0.3755 & 0.6785 & & 0.9823 & 0.9284 & 0.3404 & & 0.9969 & 0.0805 & 0.4910 \\
\hline \multirow{3}{*}{$75 / 25$} & 75 & & 0.9920 & 1.6898 & 0.5056 & & 0.9867 & 1.5953 & 0.3265 & & 0.9839 & 0.2829 & 0.6100 \\
\hline & 225 & & 0.9983 & 0.7675 & 0.5535 & & 0.9659 & 1.0545 & 0.3185 & & 0.9933 & 0.1695 & 0.5134 \\
\hline & 375 & & 0.9918 & 0.8430 & 0.5239 & & 0.9641 & 1.5575 & 0.2903 & & 0.9670 & 0.2069 & 0.4661 \\
\hline
\end{tabular}

The PAR-loaded matrices released the most drugs from $40 \%$ to $90 \%$ within $24 \mathrm{~h}$, the acidic ACE-containing ones released between $2 \%$ and $80 \%$, and the DIS-loaded systems released 6-50\% These differences cannot be explained with the different solubilities of the APIs since the applied dissolution environment ensures sink conditions for all tested drugs, and therefore the solubility may not be a limiting factor.

Nevertheless, the results of statistical analysis (Equation (5)) revealed that the main governing forces of the drug dissolution rate $\left(\mathrm{y}_{3}\right)$ are the physicochemical properties, especially the acidic strength of the drug $\left(\mathrm{x}_{3}\right)$ and the applied compression force $\left(\mathrm{x}_{1}\right)$, which confirm that the release rate is primarily determined by the porosity of the tablets, since PAR loaded matrices have the lowest hardness and highest porosity (Table 3.).

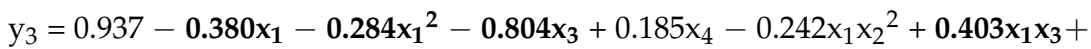

$$
\begin{aligned}
& 0.116 \mathrm{x}_{1} \mathrm{x}_{3}{ }^{2}+0.289 \mathrm{x}_{1}{ }^{2} \mathrm{x}_{3}-0.208 \mathrm{x}_{1} \mathrm{x}_{4}-0.181 \mathrm{x}_{1}{ }^{2} \mathrm{x}_{4}-0.241 \mathrm{x}_{2} \mathrm{x}_{3}-0.135 \mathrm{x}_{2} \mathrm{x}_{3}{ }^{2}+
\end{aligned}
$$

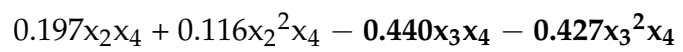

$$
\begin{aligned}
& \mathrm{R}^{2}=0.7669 \text { adj } \mathrm{R}^{2}=0.6661 \mathrm{MS} \text { Res }=0.5176
\end{aligned}
$$

The amount of excipient $\left(\mathrm{x}_{2}\right)$, and excipient used $\left(\mathrm{x}_{4}\right)$ exhibited non-significant effects on the dissolution rate, but regarding the significant factor interactions, the compressibility of the API and its possible chemical interactions with the polymer have considerable influence on drug liberation. To confirm this observation and to minimize the effect of the mechanical differences, the dissolution rates of tablets with similar porosities $(0.13 \pm 0.02)$ were compared (Figure 6a). 
(a)

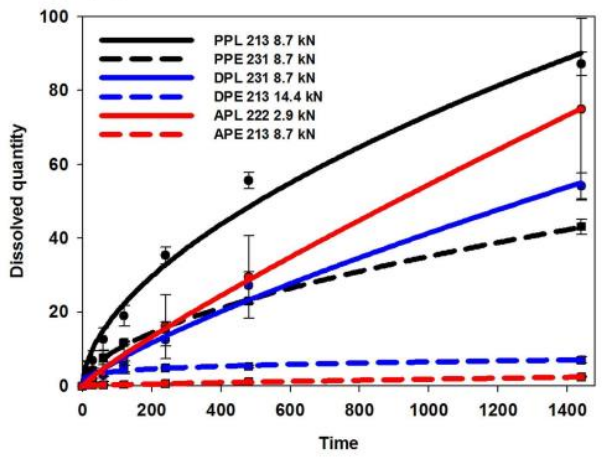

(c)

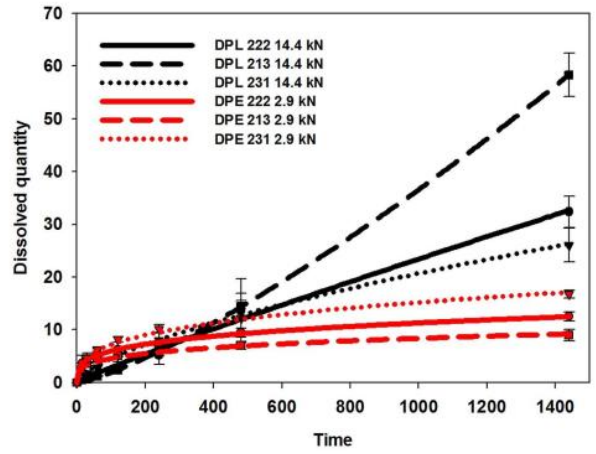

(b)

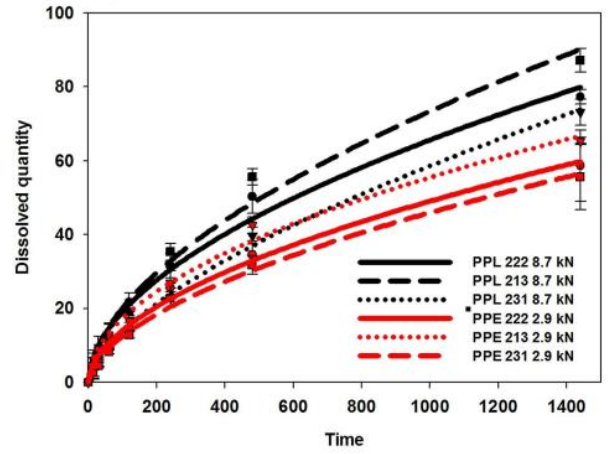

(d)

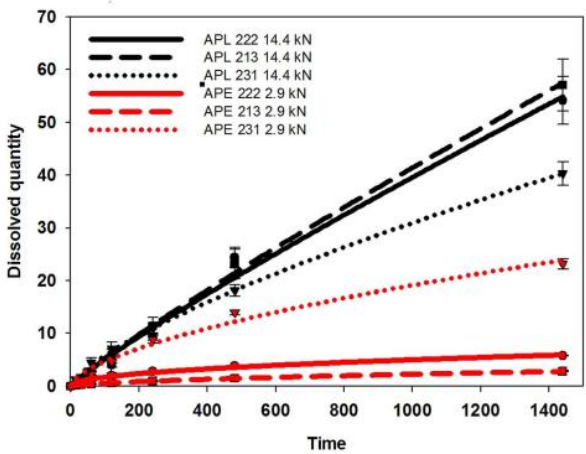

Figure 6. Drug release from various matrices: effect of the drug and polymer properties (a) and effect of the composition and compression force for PAR- (b), DIS- (c) and ACE- (d) containing matrices.

The results met the expectations since EE-based compositions exhibited considerably lower dissolution rates in all cases. Furthermore, in contrast to the observation of Mustafine et al., where in the case of acidic APIs, a dissolution rate of $100 \%$ was expected between 2 to $8 \mathrm{~h}$ with the application of EE and EL [29], slower dissolution was achieved with all tested systems, which also supports the importance of drug-matrix interactions on the dissolution rate.

The amount of the released drug decreased to $50.6 \%$ from $78.5 \%$, to $10.9 \%$ from $45.7 \%$ and to $6.2 \%$ from $58.5 \%$ in the cases of PAR-, DIS- and ACE-containing systems, respectively, if EL was switched to EE in the matrix (Figure $6 \mathrm{~b}-\mathrm{d}$ ). This may be partially explained by the increased hardness and smaller overall porosity of EE-containing samples, but the tendency is the same if the dissolution rates of samples with similar porosities are compared. In contrast, the observed results are in good accordance with the strength of drug-carrier interactions, since stronger interactions were expected between the acidic drugs and the alkaline EE. This finding supports our previous observation on the role of in situ forming drug-polymer interactions in drug dissolution [12] and were in accordance with the similar findings of Priemel et al. [30] and Mustafine et al. [31].

Finally, to confirm that the interaction-based matrix design is a suitable approach for longterm drug delivery, one-week long dissolution studies were also performed with some selected compositions. The detailed results can be found in the supplementary material.

\subsection{ANN Modelling}

ANN modelling was performed for a dual purpose: to cross check the DoE-based results on the importance of various descriptors on drug dissolution and to compare the effectiveness of kineticbased and point-to-point approaches in the predictability of the dissolution data. The use of various predictor sets may help the further clarification in which material attributes a play crucial role in the dissolution of the developed implantable matrices.

The results revealed that the overall perfection of point-to-point modelling was significantly $(p<0.05)$ better than kinetic parameter-based models $(0.92 \pm 0.02$ and $0.87 \pm 0.03$, respectively). No significant difference was observed between the prediction performance of retained networks related to the applied hidden neuron number (Table S3); the results were inconsistent and more dependent on network initialization. Similarly, the use of the various predictor sets caused no considerable change in the overall prediction performance, but an interesting difference was observed between the 
point-to-point and kinetic parameter-based models when the prediction performance was compared on the train, test, and validation subsets. In the case of kinetic parameter-based modelling, the RMSE of predictions on train $(0.22 \pm 0.08,0.15 \pm 0.07,0.09 \pm 0.05)$ and test $(0.30 \pm 0.04,0.29 \pm 0.05$, $0.19 \pm 0.05)$ datasets were significantly improved in order of Approach 1, 2 and 3, respectively, while no significant change was observed in the validation dataset. In contrast, for point-to-point modelling, the RMSE of predictions on train and test datasets remained unchanged, while it was a significant improvement on the validation dataset $(328 \pm 19,235 \pm 18,158 \pm 10)$ in order of approaches 5,4 , and 6 , respectively.

Nevertheless, despite that the observed differences can be stated, the use of continuous inputs with appropriate descriptors of the tablet texture (hardness, porosity) enabled for the best prediction performance for both point-to-point and kinetic parameter-based approaches, despite the fact that the texture parameters exhibited relatively low importance in predictivity according to the results of the global sensitivity analysis (Table S4).

The results of the global sensitivity analysis, which show the relative importance of various predictors (inputs) on prediction outcome, are partly consistent with the results of the experimental design. The greatest effect was observed for drug solubility, but the $\mathrm{pKa}$ of the excipients and the peak shift indicating drug-excipient interactions exhibited similar importance versus the compression pressure, tablet texture or the amount of excipient (Table S4).

To ultimately compare the prediction effectiveness of point-to-point and kinetic parameterbased modelling approaches, the best performing networks (best overall training perfection and lowest prediction error on validation dataset, with no negative prediction values) were selected for both modelling approaches. The best network for kinetic parameter-based modelling had nine input, seven hidden and two output neurons, with logistic activation on hidden and exponential on output neurons (training perfection: 0.9103 , validation error: 0.0760 ). The structure of the best point-to-point network was nine input, sixteen hidden, and seven output neurons, with exponential activation on hidden neurons and logistic on output neurons (training perfection: 0.9286, validation error: 83.06). Figure 7 shows the predicted dissolution curves of the best and worst predicted cases.

(a)

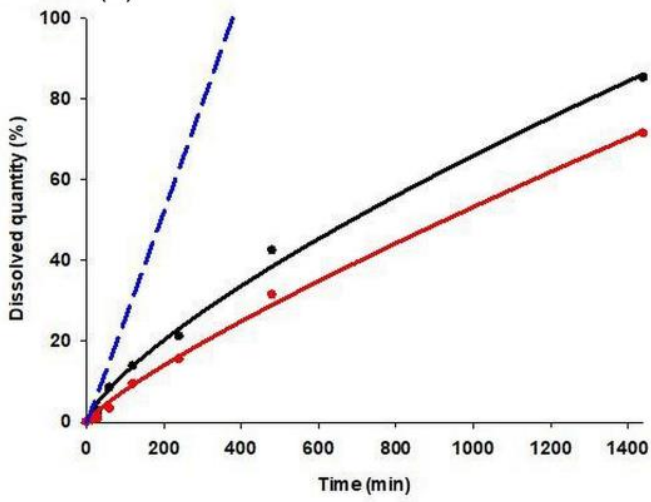

(c)

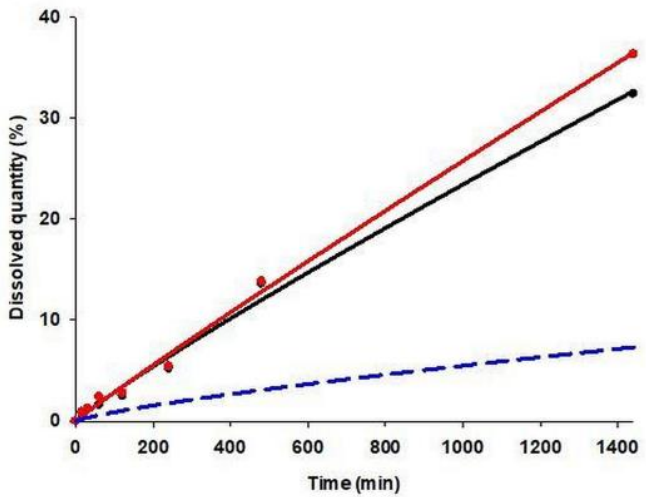

(b)

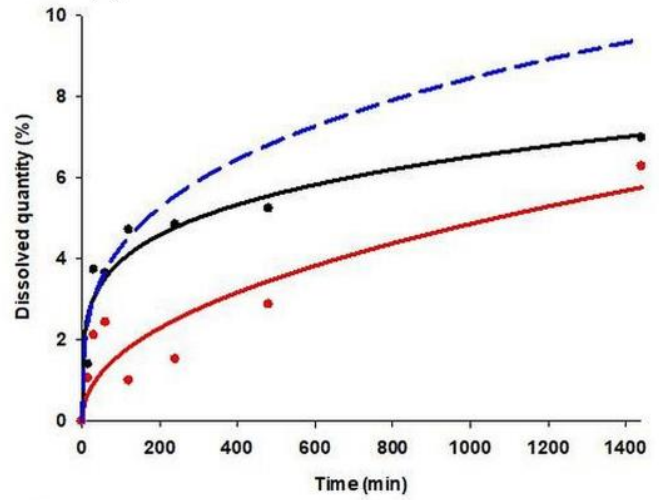

(d)

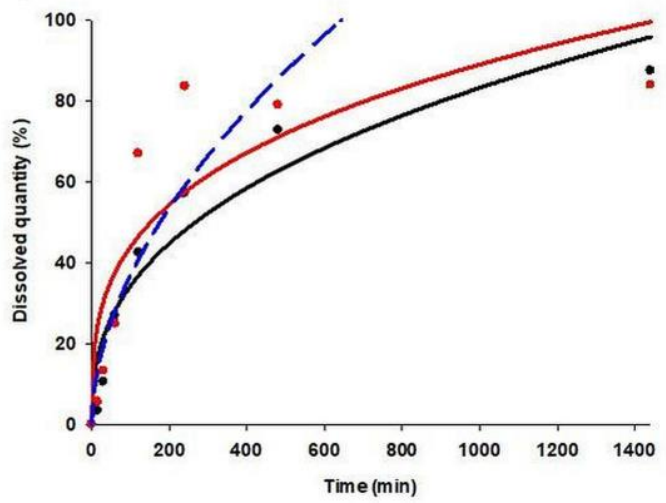

Figure 7. Observed and predicted dissolution curves of case 43 (a), case 36 (b), case 24 (c) and case 7 (d). Black dots: observed data points; black line: fitted model on observed data; red dots: predicted data points; red line: fitted model on predicted data points; blue line: predicted model. 
It is clearly visible that the point-to-point modelling approach showed more consistent accuracy, especially in cases where drug release was nearly linear (Figure $7 \mathrm{a}, \mathrm{c}$ ). In other cases, the most considerable inaccuracies were observed at the 2,4 , and $8 \mathrm{~h}$ data points. Nevertheless, the predicted results were closer to the observed ones as for kinetic parameter-based models.

The main problem of the kinetic parameter-based approaches is that the dissolution data obtained show large differences; thus, the corresponding dissolution rates were scattered by two orders of magnitude. This posed a certain limitation on the predictivity since small inaccuracies in the predicted values of low release rates resulted in predictions of 3-5-fold faster or slower dissolution (Figure $7 \mathrm{a}, \mathrm{c}$ ). The prediction of release exponents, which scattered in a significantly smaller range, was more accurate, but the presence of small inaccuracies can also cause large differences between the observed and predicted data at the end of the dissolution curves. It can be stated that the obtained models provide the desired accuracy only in the first $4-8 \mathrm{~h}$ of dissolution (Figure $7 \mathrm{~b}, \mathrm{~d}$ ).

\section{Conclusions}

The present study introduced a comprehensive systematic approach for the investigation of the role of chemical interactions between APIs and excipients in directly compressed matrices. With the help of FT-IR studies, it was confirmed that solid-state interactions may be induced in directly compressed matrix systems. The results also confirmed that the presence of solid-state interactions may not always present in directly compressed systems, but their presence will definitely predict strong in situ forming interactions during the drug dissolution process. The interactions are mostly $\mathrm{H}$-bond based, but the forming of polyelectrolyte complexes cannot be excluded. The results of both DoE analysis and the ANN modelling supported our primary hypothesis that API-excipient interactions have a considerable effect on drug release by retaining the drug in the matrix.

The secondary hypothesis that kinetic parameters can be effectively used as an output in predicting drug release during ANN modelling has not been substantiated. The simplified structure did not result in a faster generalization of the network, and due to the wide scatter of the output results, small variations in the predicted release rate caused a high degree of uncertainty in the predicted dissolution curves. In contrast, when a point-to-point approach is used, the difference between the observed and predicted data at a given time can be compensated for at other time points. Therefore, applying a point-to-point approach provides greater reliability and more reliable predictions.

Nevertheless, the above-mentioned limitations can be overcome by increasing the number of cases, which makes it possible to fill in the gaps in the training data set. Therefore, the combination of interaction factors and ANN-based modelling may be a promising way to design extended-release products, especially implantable systems with tailored dissolution properties.

Supplementary Materials: The following supporting information can be downloaded at: https:/ / www. mdpi.com/article/10.3390/pharmaceutics14020228/s1, Table S1: Dataset of the ANN modelling; Figure S1 FT-IR spectra (650-1800 $\mathrm{cm}^{-1}$ range) of the DIS (black); DIS-PVC:EL 75:25 (red); DIS-PVC:EL 50:50 (green); DIS-PVC:EL 25:75 (deep blue); EL (light blue) and PVC (purple) samples; Figure S2. FT-IR spectra (650-1800 $\mathrm{cm}^{-1}$ range) of the DIS (black); DIS-PVC:EE 75:25 (red); DIS-PVC:EE 50:50 (green); DIS-PVC:EE 25:75 (deep blue); EE (light blue) and PVC (purple) samples; Figure S3. FT-IR spectra of Dis-PVC:EE 75:25 samples: original (black), dipped (red), and dried (green); Figure S4. FT-IR spectra of Dis-PVC:EL 75:25 samples: original (black), dipped (red), and dried (green); Figure S5: FT-IR spectra (650-1800 $\mathrm{cm}^{-1}$ range) of the PAR (black); PAR-PVC:EL 75:25 (red); PAR-PVC:EL 50:50 (green); PAR-PVC:EL 25:75 (deep blue); EL (light blue) and PVC (purple) samples; Figure S6: FT-IR spectra (650-1800 $\mathrm{cm}^{-1}$ range) of the PAR (black); PAR-PVC:EE 75:25 (red); PAR-PVC:EE 50:50 (green); PAR-PVC:EE 25:75 (deep blue); EE (light blue) and PVC (purple) samples; Figure S7. FT-IR spectra of Par-PVC:EE 75:25 samples: original (black), dipped (red), and dried (green); Figure S8. FT-IR spectra of Par-PVC:EL 75:25 samples: original (black), dipped (red), and dried (green); Table S2. Release rates and release exponents derived from the Korsmeyer-Peppas model (1-week-long test); Figure S9. Drug release from various matrices: effect of the drug and polymer properties (a) and effect of the composition and compression force for PAR (b), DIS (c) and ACE (d) containing matrices; Table S3: Performance of the neurons; Table S4: Results of the global sensitivity analysis.

Author Contributions: Conceptualization, T.S. and S.S.; Formal Analysis, E.B., K.K. and I.G.I.; Investigation, E.B. and I.G.I.; Methodology, T.S. and K.P.-H.; Project Administration, G.R.J.; Supervision, T.S. and S.S.; Validation, T.S.; Visualization, E.B.; Writing-Original Draft Preparation, E.B.; WritingReview and Editing, T.S., G.R.J., I.C. and S.S. All authors have read and agreed to the published version of the manuscript. 
Funding: The research was supported by CEEPUS MOBILITY: CIII-RS-1113-01-1718-M-113871. Project no. TKP2021-EGA-32 has been implemented with the support provided by the Ministry of Innovation and Technology of Hungary from the National Research, Development, and Innovation Fund, financed under the TKP2021-EGA funding scheme.

Institutional Review Board Statement: Not applicable.

Informed Consent Statement: Not applicable.

Data Availability Statement: The detailed dataset of ANN predictions in this study are available on request from the corresponding author due size and file format.

Acknowledgments: This topic is respectfully dedicated to Piroska Szabó-Révész for her scientific support and research motivation in the field of innovative drug formulation. Her scholarly work and intellectual advice play a vital role in past and current scientific achievements of the Institute of Pharmaceutical Technology and Regulatory Affairs, University of Szeged.

Conflicts of Interest: The authors declare no conflict of interest.

\section{References}

1. Crowley, M.M.; Schroeder, B.; Fredersdorf, A.; Obara, S.; Talarico, M.; Kucera, S.; McGinity, J.W. Physicochemical properties and mechanism of drug release from ethyl cellulose matrix tablets prepared by direct compression and hot-melt extrusion. Int. J. Pharm. 2004, 269, 509-522. [CrossRef] [PubMed]

2. Korsmeyer, R.W.; Gurny, R.; Doelker, E.; Buri, P.; Peppas, N.A. Mechanisms of solute release from porous hydrophilic polymers. Int. J. Pharm. 1983, 15, 25-35. [CrossRef]

3. Lee, P.I.; Peppas, N.A. Prediction of polymer dissolution in swellable controlled-release systems. J. Control. Release 1987, 6, 207-215. [CrossRef]

4. Campos-Aldrete, M.E.; Villafuerte-Robles, L. Influence of the viscosity grade and the particle size of HPMC on metronidazole release from matrix tablets. Eur. J. Pharm. Biopharm. 1997, 43, 173-178. [CrossRef]

5. Huanbutta, K.; Cheewatanakornkool, K.; Terada, K.; Nunthanid, J.; Sriamornsak, P. Impact of salt form and molecular weight of chitosan on swelling and drug release from chitosan matrix tablets. Carbohydr. Polym. 2013, 97, 26-33. [CrossRef]

6. Thomas, N.; Windle, A. A theory of case II diffusion. Polymers 1982, 23, 529-542. [CrossRef]

7. Kaunisto, E.; Alami, S.A.; Borgquist, P.; Larsson, A.; Nilsson, B.; Axelsson, A. A mechanistic modelling approach to polymer dissolution using magnetic resonance microimaging. J. Control. Release 2010, 147, 232-241. [CrossRef] [PubMed]

8. Singh, B.; Dhiman, A.; Kumar, A. Slow release of ciprofloxacin from $\beta$-cyclodextrin containing drug delivery system through network formation and supramolecular interactions. Int. J. Biol. Macromol. 2016, 92, 390-400. [CrossRef]

9. Deaconu, M.; Brezoiu, A.-M.; Mitran, R.-A.; Nicu, I.; Manolescu, B.; Matei, C.; Berger, D. Exploiting the zwitterionic properties of lomefloxacin to tailor its delivery from functionalized MCM-41 silica. Microporous Mesoporous Mater. 2020, 305, 110323. [CrossRef]

10. Huang, J.; Jacobsen, J.; Larsen, S.; Genina, N.; van de Weert, M.; Müllertz, A.; Nielsen, H.; Mu, H. Graphene oxide as a functional excipient in buccal films for delivery of clotrimazole: Effect of molecular interactions on drug release and antifungal activity in vitro. Int. J. Pharm. 2020, 589, 119811. [CrossRef] [PubMed]

11. De Robertis, S.; Bonferoni, M.C.; Elviri, L.; Sandri, G.; Caramella, C.; Bettini, R. Advances in oral controlled drug delivery: The role of drug-polymer and interpolymer non-covalent interactions. Expert Opin. Drug Deliv. 2014, 12, 441-453. [CrossRef]

12. Sovány, T.; Csüllög, A.; Benkő, E.; Regdon, G.; Pintye-Hódi, K. Comparison of the properties of implantable matrices prepared from degradable and non-degradable polymers for bisphosphonate delivery. Int. J. Pharm. 2017, 533, 364-372. [CrossRef] [PubMed]

13. Caputo, A.; Brocca-Cofano, E.; Castaldello, A.; De Michele, R.; Altavilla, G.; Marchisio, M.; Gavioli, R.; Rolen, U.; Chiarantini, L.; Cerasi, A.; et al. Novel biocompatible anionic polymeric microspheres for the delivery of the HIV-1 Tat protein for vaccine application. Vaccine 2004, 22, 2910-2924. [CrossRef] [PubMed]

14. Schlocker, W.; Gschließer, S.; Bernkop-Schnürch, A. Evaluation of the potential of air jet milling of solid protein-poly(acrylate) complexes for microparticle preparation. Eur. J. Pharm. Biopharm. 2006, 62, 260-266. [CrossRef] [PubMed]

15. Ali, M.E.; Lamprecht, A. Polyethylene glycol as an alternative polymer solvent for nanoparticle preparation. Int. J. Pharm. 2013, 456, 135-142. [CrossRef] [PubMed]

16. Hari, B.V.; Narayanan, N.; Dhevendaran, K.; Ramyadevi, D. Engineered nanoparticles of Efavirenz using methacrylate co-polymer (Eudragit-E100) and its biological effects in-vivo. Mater. Sci. Eng. C 2016, 67, 522-532. [CrossRef]

17. Thomas, T.T.; Kohane, D.S.; Wang, A.; Langer, R. Microparticulate Formulations for the Controlled Release of Interleukin. J. Pharm. Sci. 2004, 93, 1100-1109. [CrossRef]

18. Basarkar, A.; Singh, J. Poly (lactide-co-glycolide)-Polymethacrylate Nanoparticles for Intramuscular Delivery of Plasmid Encoding Interleukin-10 to Prevent Autoimmune Diabetes in Mice. Pharm. Res. 2009, 26, 72-81. [CrossRef] [PubMed]

19. Balaguer-Fernández, C.; Femenía-Font, A.; del Rio-Sancho, S.; Merino, V.; López-Castellano, A. Sumatriptan Succinate Transdermal Delivery Systems for The Treatment of Migraine. J. Pharm. Sci. 2008, 97, 2102-2109. [CrossRef] [PubMed] 
20. Sovány, T.; Kása, P.; Pintye-Hódi, K. Modeling of subdivision of scored tablets with the application of artificial neural networks. J. Pharm. Sci. 2010, 99, 905-915. [CrossRef]

21. Sovány, T.; Papós, K.; Kása, P., Jr.; Ilič, I.; Srčič, S.; Pintye-Hódi, K. Application of physicochemical properties and process parameters in the development of a neural network model for prediction of tablet characteristics. AAPS PharmSciTech 2013, 14, 511-516. [CrossRef]

22. Galata, D.L.; Farkas, A.; Könyves, Z.; Mészáros, L.A.; Szabó, E.; Csontos, I.; Pálos, A.; Marosi, G.; Nagy, Z.K.; Nagy, B. Fast, Spectroscopy-Based Prediction of In Vitro Dissolution Profile of Extended Release Tablets Using Artificial Neural Networks. Pharmaceutics 2019, 11, 400. [CrossRef] [PubMed]

23. Jangir, D.K.; Charak, S.; Mehrotra, R.; Kundu, S. FTIR and circular dichroism spectroscopic study of interaction of 5-fluorouracil with DNA. J. Photochem. Photobiol. B Biol. 2011, 105, 143-148. [CrossRef] [PubMed]

24. Mihaylov, M.Y.; Ivanova, E.; Vayssilov, G.N.; Hadjiivanov, K.I. Revisiting ceria-NOx interaction: FTIR studies. Catal. Today 2020, 357, 613-620. [CrossRef]

25. Liu, X.; Ma, X.; Kun, E.; Guo, X.; Yu, Z.; Zhang, F. Influence of lidocaine forms (salt vs. freebase) on properties of drugeudragit ${ }^{\circledR L} 100-55$ extrudates prepared by reactive melt extrusion. Int. J. Pharm. 2018, 547, 291-302. [CrossRef]

26. Obeidat, W.M.; Nokhodchi, A.; Alkhatib, H. Evaluation of Matrix Tablets Based on Eudragit@E100/Carbopol®971P Combinations for Controlled Release and Improved Compaction Properties of Water Soluble Model Drug Paracetamol. AAPS PharmSciTech 2015, 16, 1169-1179. [CrossRef]

27. Pavli, M.; Baumgartner, S.; Kos, P.; Kogej, K. Doxazosin-carrageenan interactions: A novel approach for studying drug-polymer interactions and relation to controlled drug release. Int. J. Pharm. 2011, 421, 110-119. [CrossRef]

28. Ritger, P.L.; Peppas, N.A. A simple equation for description of solute release. J. Control. Release 1987, 5, 23-36. [CrossRef]

29. Moustafine, R.I.; Zaharov, I.M.; Kemenova, V.A. Physicochemical characterization and drug release properties of Eudragit ${ }^{\circledR E}$ PO/Eudragit ${ }^{\circledR} L$ 100-55 interpolyelectrolyte complexes. Eur. J. Pharm. Biopharm. 2006, 63, 26-36. [CrossRef]

30. Priemel, P.A.; Laitinen, R.; Grohganz, H.; Rades, T.; Strachan, C. In situ amorphisation of indomethacin with Eudragit ${ }^{\circ E}$ during dissolution. Eur. J. Pharm. Biopharm. 2013, 85, 1259-1265. [CrossRef]

31. Moustafine, R.I.; Sitenkov, A.Y.; Bukhovets, A.V.; Nasibullin, S.F.; Appeltans, B.; Kabanova, T.V.; Khutoryanskiy, V.; Mooter, G.V.D. Indomethacin-containing interpolyelectrolyte complexes based on Eudragit ${ }^{\circledR E} \mathrm{PO} / \mathrm{S} 100$ copolymers as a novel drug delivery system. Int. J. Pharm. 2017, 524, 121-133. [CrossRef] [PubMed] 